\title{
Green Open Space Planning in Improving the Quality of Space in the Mamuju Urban Area
}

\author{
Dian Awaliah Marsawal ${ }^{1}$, Hazairin Zubair $^{2}$, Andang Suryana Soma ${ }^{3}$ \\ *Corresonding Email: mdianawaliah66@gmail.com \\ ${ }^{1}$ Regional Development Planning, Postgraduate, Hasanuddin University, Indonesia \\ ${ }^{2}$ Faculty of Agriculture, Hasanuddin University, Indonesia \\ ${ }^{3}$ Faculty of Forestry, Hasanuddin University, Indonesia
}

\begin{abstract}
The increase in regional demographics certainly affects the use of energy for transportation and households which will ultimately have implications for greenhouse gas (CO2) emissions in the region. This study focuses on the planning of green open space in the Mamuju Urban Area in order to minimize the effects of greenhouse gases so that the quality of space in the area is maintained. This research is a type of quantitative descriptive research that explores the condition of green open space in the Mamuju Urban Area and takes into account the existing emission potential. The data analysis used is AHP (scoring and weighting) to determine the value and influence of each thematic, image digitization and field observations to determine the existing green open space in the Mamuju Urban Area, and overlay using the ArcGIS 10.8 application to combine maps that be a research indicator. The results obtained from this study are that the Mamuju Urban Area continues to grow from time to time, the distribution of existing green open space continues to decrease along with land use changes that continue to occur, and from the analysis of potential emissions, the largest green open space planning directive is private green open space planning with an area of 354, $14 \mathrm{Ha}$.
\end{abstract}

Keywords: Planning, Green Open Space, Urban

Received: May 5, 2021

Revised: June 13, 2021

Accepted: June 29, 2021

\section{Introduction}

Regional expansion policies always have positive and negative impacts on an area. The expansion of the region gives the region the authority to manage its own household according to the resources they have, this is expected to motivate the region to innovate and develop itself in order to compete with regions that have developed beyond it. However, sometimes an area develops in terms of infrastructure but declines in terms of environmental management.

Urbanization is an event that occurs in almost all countries but the pattern and results are not always the same in every place, urbanization can also have implications for several factors such as economic transformation and an increase in urban demography (Dyson, 2011; Buhaug \& Urdal, 2013; Farrell, 2017). Mamuju is one of the destinations for urbanization, Mamuju in 2018 figures shows the population growth rate of Mamuju from 2010 to 2017 reached nearly 50,000 people from 231,324 in 2010 and in 2017 there were 272,258 people, in line with the projected population that has conducted by BPS in 2013 with an increasing trend of $22.59 \%$ in the 2010-2020 period (A \& Nuraini, 2015).

Without us realizing it, the development of an area so far has always been the main cause of the conversion of green open space into a built area which causes reduced oxygen production due to the decreasing number of green vegetation (Sesanti et al., 2011; Nastiti \& Giyarsih, 2019). The development of the area cannot be separated from the increase in population which

Copyright @ 2021, International Journal Papier Public Review, Under the license CC BY-SA 4.0 DOI: https://doi.org/10.47667/ijppr.v2i3.99 
is one of the main problems in the development of an area because these factors are the reason for the development of residential areas, facilities and infrastructure, these factors also have an impact on changes in land use both for settlements, urban green areas or other designations (Ruslan \& Rahmad, 2012).

In addition, the increase in population will be in line with the increase in means of transportation which are one of the primary needs of urban communities and of course affect the use of fuel and the volume of air pollution from motor vehicle exhaust gases which will have implications for GHG (greenhouse gases). The use of BBM in Mamuju Regency is based on data recapitulated from four sources, namely PT. Pertamina, PT. Multi Trading, Patra Niaga, and PT. Jagad Energy by the Regional Financial and Asset Management Agency (BPKAD) of West Sulawesi Province has increased by almost 4,000,000 liters, from 55,514,385 liters in 2017 and in 2019 it reached 59,593,459 liters. This figure certainly has a significant effect on the GHG produced, the impact of which can be minimized with adequate green open space.

Nurisjah (Fatimah et al., 2011) mentions that green open spaces have ecological functions that will support environmental quality such as absorbing carbon in the photosynthesis process, absorbing air pollution so as to maintain and improve air freshness quality, besides that green open spaces also have the ability to slow down the rate of surface runoff and ameliorate urban microclimate. This statement is in line with the results of Irwan's research (Ahmad et al., 2012) who explained that one thing that really needs to be developed in urban areas is plants or the cultivation of green vegetation because of their ability to bind $\mathrm{CO} 2$ or carbon dioxide and produce oxygen $(\mathrm{O} 2)$ and release it back into the air through the process of photosynthesis with the help of sunlight.

The existence and management of public sector green open spaces is the responsibility of local governments. The fulfillment of green open space as mandated by Law No. 26 of 2007 of $30 \%$ of the city area is expected to be realized in Mamuju with an attractive arrangement so that it can become a special attraction for the area.

One of the things that the government needs to do is to plan the development of green open spaces for the effectiveness and equitable distribution of green open space development in the public sector in Mamuju. Through planning, the government can detect priority locations for the development of green open spaces and consider their needs in the Mamuju area, especially strategic areas such as the Mamuju Urban Area. In addition, it is hoped that the development of green open space can create climate stability in the Mamuju area with an accurate distribution.

The pattern of distribution of green open space in Mamuju Regency is scattered (scattered). As for the Mamuju and Simboro sub-districts, which are urban centers (Mamuju Urban Area) and the government, the land cover is dense with housing, warehouses, and office buildings (Mamuju, 2019). Based on data from the Department of Housing, Settlement and Land Affairs of Mamuju Regency, in 2017 there were 55 (fifty five) points of existing green open space in Mamuju District and 30 (thirty) points in Simboro District which were spread unevenly in the two sub-districts. The data cannot be used as a reference because the condition of the data has not been updated for 2019. Furthermore, the results of interviews with the Lariang Mamasa Watershed Management and Protection Forest Management Center, there is an urban forest procurement in Mamuju District which was last implemented in 2010 and its management has been handed over to the Government The district (currently the district forestry affairs have become the responsibility of the provincial government) and after being confirmed with the West Sulawesi Provincial Forestry Service there is no accurate data regarding urban forest 
management mentioned by the Lariang Mamasa Watershed Management and Protection Forest Management Center.

From the initial information obtained in the field, it gives a little picture that the management of green open space in Mamuju Regency has not been implemented properly. The problem of green open space is a complex matter which if not implemented properly will have an impact on environmental sustainability in the future. From some of the conditions described in the background above, several problems are formulated that are deemed necessary to be studied in this research, namely the development of the Mamuju Urban Area, the existing condition of green open spaces, the distribution of potential greenhouse gas (CO2) emissions, as well as the direction of the open space development plan. in the Mamuju Urban Area to improve space quality and maximize land use.

\section{Methods}

This research is a type of quantitative research. This study aims to explore the factual conditions of green open space and take into account the potential for greenhouse gas (CO2) emissions in the Mamuju Urban Area which is the center of community development, government, and services in the Mamuju Regency area, then compare the results of these observations with the conditions of green open spaces that are planned in the RTRW (Neighborhood Association/Hamlet Association) of Mamuju Regency, then formulate the direction of the green open space development plan which should be developed based on the needs of the community and the environment by first analyzing the emission level in the area. This research was carried out using the Arcgis 10.8 application for processing spatial data by digitizing Landsat 8 Year 2020 images combined with high resolution imagery, reclassify and overlapping maps, field observations and visits to related work units to collect research data and information.

The research was carried out in West Sulawesi Province, precisely in Mamuju Regency, which focused on 2 (two) sub-districts which became the center of urban activity because it is one of the district's strategic areas or in Law Number 26 of 2007 concerning Spatial Planning it is stated that the district/city strategic area is an area whose spatial planning is prioritized because it has a very important influence within the scope of a district/city on the economy, social, culture and/or environment. The Mamuju Urban Area which was developed by the local government to support the development of the Mamuju Regency area includes 4 (four) urban villages in the Mamuju District, namely Binanga Village, Mamunyu Village, Rimuku Village, and Karema Village, as well as 2 (two) villages in the Simboro District area, namely Simboro Village and Rangas Village, the 6 (six) villages have a total area of $378.28 \mathrm{~km} 2$ or $7.6 \%$ of the total area of Mamuju Regency which has an area of 4,999.69 km2.

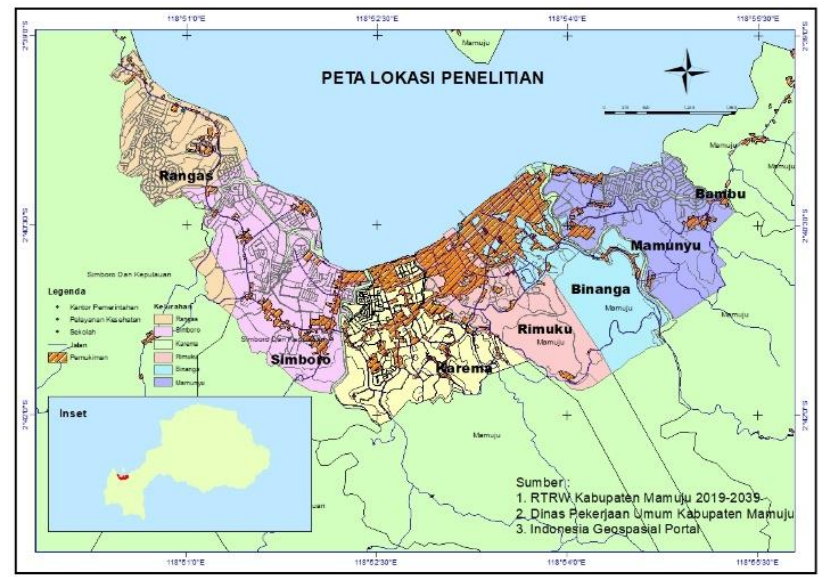


Figure 1. Research Location Map

The study was conducted from August to December 2020. This study used primary and secondary data. Primary data is data obtained directly by researchers, primary data in this study were obtained through surveys and direct observations in the field. While secondary data is in the form of data that has been processed by certain parties such as related work units that handle certain data, and has been published. The secondary data in this study are the Mamuju RTRW, data on the distribution of the population of the Mamuju Urban Area, data on the potential of villages/kelurahan in the Mamuju Urban Area, data on the use of BBM in Mamuju Regency, data on existing green open spaces in Mamuju Regency in 2017, administrative maps of Mamuju Regency, maps of the distribution of open spaces. Existing green area of Mamuju Regency in 2019, map of population density of Mamuju Urban Area, map of road network of Mamuju Urban Area, Map of land cover of Mamuju Urban Area, map of disaster prone area of Mamuju Urban Area.

The supporting tools used in this research are a computer set with ArcGIS 10.8 software for geometric correction, digitization and map processing. In addition, the existing green open space is obtained through the use of Landsat 8 imagery in 2020. Other supporting tools needed in this research are GPS (Global Positioning System) for field checking and taking coordinates of research locations, as well as Microsoft Excel for calculations and processing. mathematical data.

Data analysis techniques that will be used in this study are as follows:

\section{Identify existing green open spaces}

Identification of the distribution of green open space with Landsat 8 Imagery in 2020 combined with high resolution imagery. Identification of land cover here can make it easier for researchers to find out existing green open spaces that still survive in the Mamuju Urban Area.

\section{Spatial analysis of greenhouse gas (CO2) emissions in the Mamuju Urban Area}

This stage will produce an emission map output in the Mamuju Urban Area with the data analysis stage using AHP, namely scoring and weighting the emission potential in the Mamuju Urban Area, the scoring stage and the weighting of 4 (four) indicators in pairs, after that make a reclassify of these indicators (density map). road network, land use maps, disaster-prone maps, and population density maps) using the ArcGIS 10.8 application which then goes through the overlay stage to produce a map of the distribution of emission potential from all existing data (in the form of emission potential categories) which is then calculated per category. And the last stage of this spatial analysis is the overlay of the emission potential map with the RTRW map of the Mamuju Urban Area and the existing map of green open space.

\section{Identifying green open space planning directions in the Mamuju Urban Area}

The final result of the spatial analysis produced a map with emission potential classes in the Mamuju Urban Area, then analyzed the condition of the plan in the RTRW of Mamuju Regency 2019-2039 to see land use in areas with "very high" and "high" emission potential classes and observed the presence of open space in the area. the two regional categories. From the results of observations, it is determined the direction of green open space planning for each zone in order to minimize emissions in the Mamuju Urban Area 


\section{Results and Discussion}

\section{Existing Green Open Space}

Existing green open space is analyzed through Landsat 8 imagery in 2020 which is combined with high resolution imagery and displays the existing green open space in the Mamuju Urban Area with an area of $320.04 \mathrm{Ha}$ in the form of parks, educational facilities, worship facilities, sports facilities, road median lanes, and border areas. river. The existing green open space in the Mamuju Urban Area is spread over 33 points, while in 2016 the green open space in the Mamuju Urban Area is located at 55 (fifty five) points consisting of sports facilities, median roads, parks, educational facilities, health facilities worship and more (Mamuju, 2019). This shows that the area of green open space in the Mamuju Urban Area continues to decrease from time to time. The distribution of the existing green open space can be seen in Figure 2.

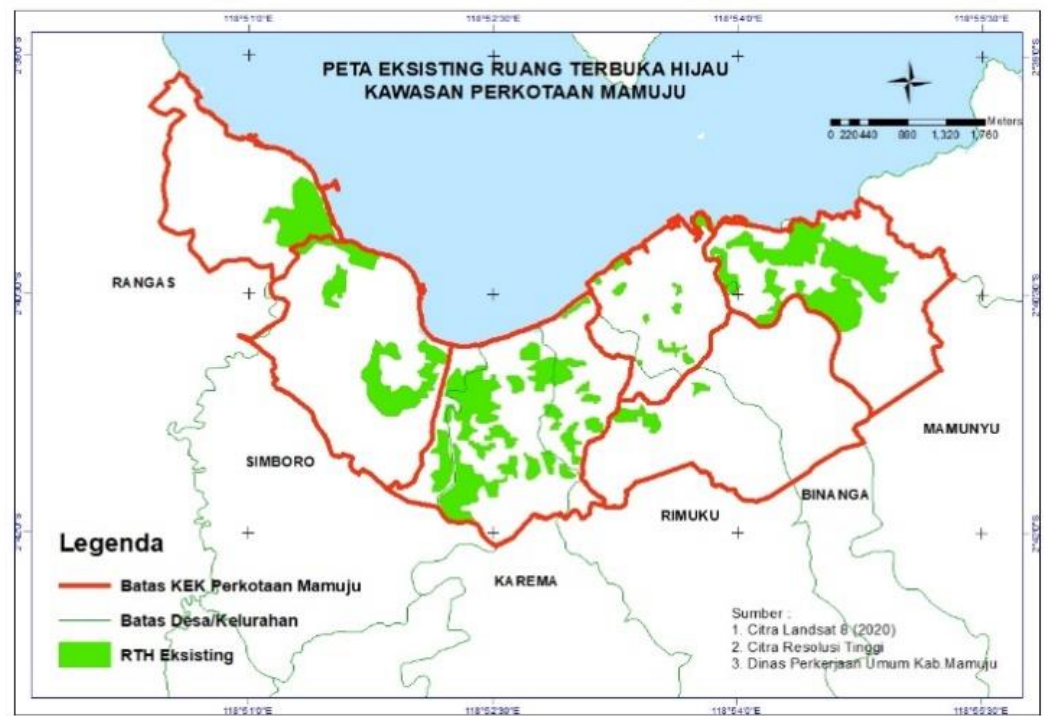

Figure 2. Map of Green Open Space in Mamuju Urban Area

\section{Emission Potential Analysis}

Emission potential was analyzed by weighting 4 (four) variables in pairs using the Analytical Hierarchy Process (AHP) method with weighting values based on expert judgment analysis (expert validity). The results of the weighting of these variables can be seen in Table 1.

Table 1. Weight and Effect of Variables on Emissions in the Mamuju Urban Area using the AHP method

\begin{tabular}{|c|c|c|c|c|c|r|}
\hline & JJ & PL & RB & KP & Total & Weight \\
\hline JJ & 1 & 0,6 & 0,7 & 0,7 & 3 & $\mathbf{3 0 \%}$ \\
\hline PL & 0,4 & 1 & 0,7 & 0,7 & 2,8 & $\mathbf{2 8 \%}$ \\
\hline RB & 0,3 & 0,3 & 1 & 0,4 & 2 & $\mathbf{2 0 \%}$ \\
\hline KP & 0,3 & 0,3 & 0,6 & 1 & 2,2 & $\mathbf{2 2 \%}$ \\
\hline & & & & & 10 & $\mathbf{1 0 0 \%}$ \\
\hline
\end{tabular}


Description :

JJ : Road Network RB : Prone to Disaster

PL : Land Use KP : Population Density

The next stage is the scoring of four indicators, namely road network, land use, disaster-prone, and population density with five classification values, namely 10 (very low) to 50 (very high) according to the emission potential level of each variable. The scoring results from the four thematic maps are then multiplied by the weights in table 1 generated from the AHP method to get the emission potential value based on the thematic map.

\section{Emission Potential based on Road Network Density}

The analysis of the Mamuju road network map is classified into 5 (five) classes, namely very low, low, medium, high, very high. The road density radius was analyzed with a density radius of $1 \mathrm{Ha}$. The road network map for the Mamuju Urban Area can be seen in Figure 3

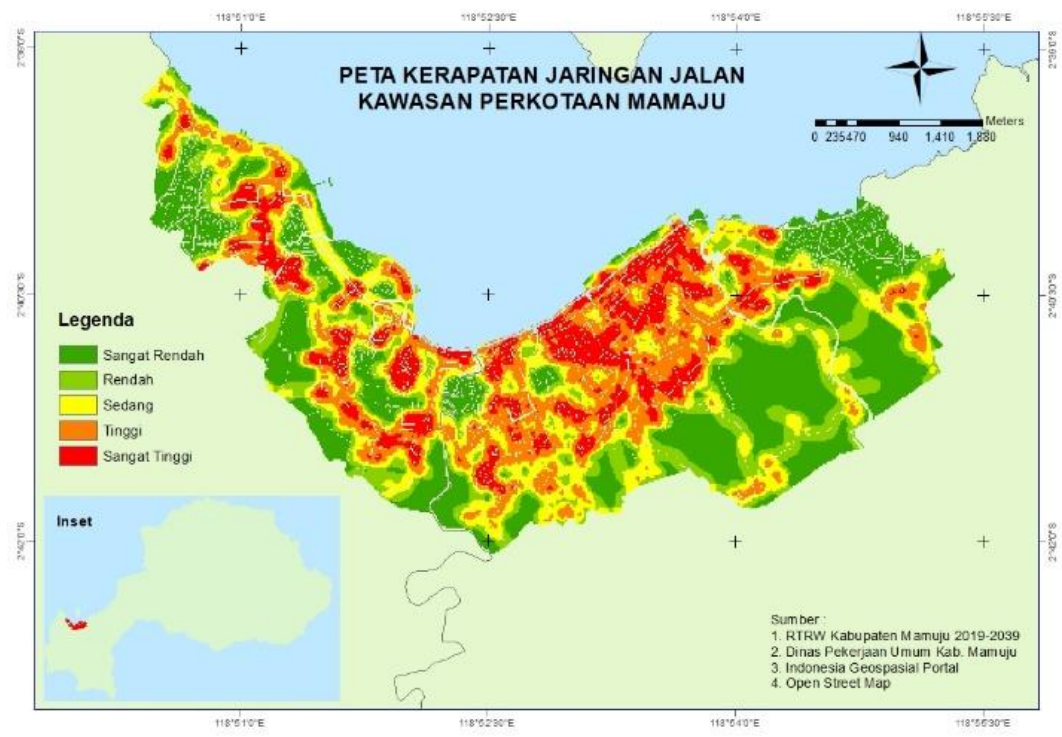

Figure 3. Map of the Road Network Density of the Mamuju Urban Area

From the map above, the potential emissions resulting from the density of the road network in the Mamuju Urban Area are analyzed in Table 2.

Table 2. Potential Emissions based on Road Network Density in Mamuju Urban Area

\begin{tabular}{|c|c|c|c|c|c|c|}
\hline Indicator & Score & Weight & $\begin{array}{c}\text { Score x } \\
\text { Weight }\end{array}$ & $\begin{array}{c}\text { Emission } \\
\text { Potential }\end{array}$ & $\begin{array}{c}\text { Surface } \\
\text { (Ha) }\end{array}$ & $\%$ \\
\hline Very low & 10 & 0,30 & 3,00 & Very low & 603,23 & 30,54 \\
\hline Low & 20 & 0,30 & 6,00 & Low & 330,21 & 16,72 \\
\hline Medium & 30 & 0,30 & 9,00 & Medium & 372,37 & 18,85 \\
\hline High & 40 & 0,30 & 12,00 & High & 420,69 & 21,30 \\
\hline Very high & 50 & 0,30 & 15,00 & Very high & 248,54 & 12,58 \\
\hline
\end{tabular}

From the mapping of the road network, the resulting area with a very high emission potential density of the road network is $248.54 \mathrm{Ha}$ or $12.58 \%$ of the Mamuju Urban Area, the high category density is $420.69 \mathrm{Ha}$ or $21.30 \%$ of the Urban Area, the density of the high category is 
420.69 Ha or $21.30 \%$ of the Urban Area. medium $372.37 \mathrm{Ha}$, low density $330.21 \mathrm{Ha}$, and very low density covering an area of $603.23 \mathrm{Ha}$ or $30.54 \%$ of the Urban Area.

\section{Potential Emissions by Land Use}

The land use map that has been analyzed through the Arcgis application has its own attribute data, then each attribute is assigned a value or score based on expert judgment (expert validity) with a range of values from 10 to 50 and the emission categories are very high, high, medium, low, and very low. low. The results of the next classification are made in thematic form which can be seen in Figure 4.

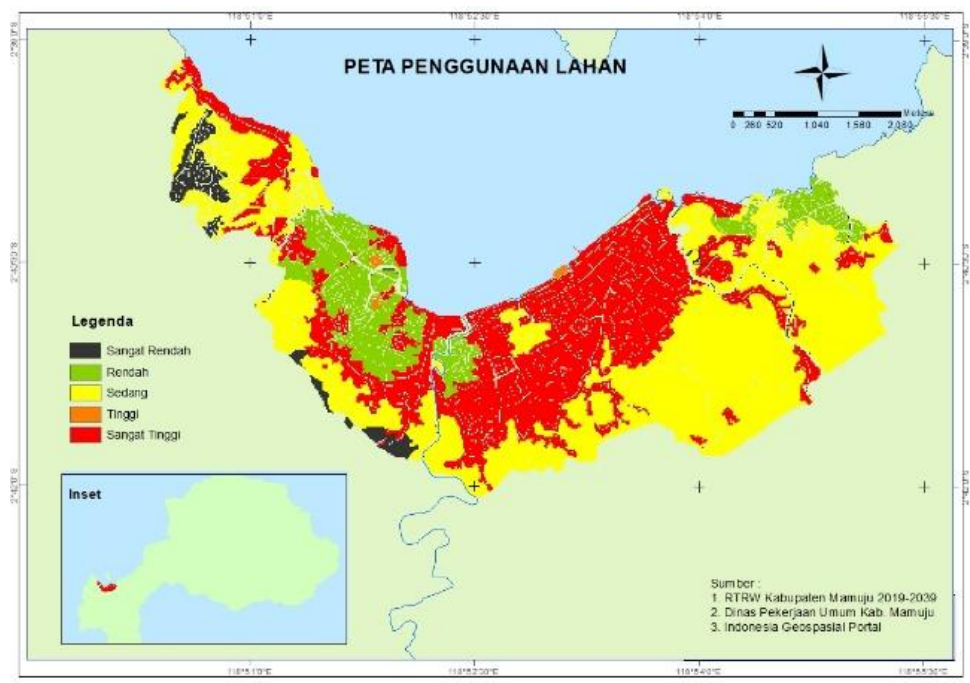

Figure 4. Map of Potential Emissions from Land Use

From the map above, the potential emissions from land use in the Mamuju Urban Area can be seen in Table 3.

Table 3. Potential Emissions by Land Use

\begin{tabular}{|l|c|c|c|c|c|c|}
\hline \multicolumn{1}{|c|}{ Land Use } & Score & Weight & $\begin{array}{c}\text { Score } \\
\text { Xeight }\end{array}$ & $\begin{array}{c}\text { Emission } \\
\text { Potential }\end{array}$ & $\begin{array}{c}\text { Surface } \\
\text { (Ha) }\end{array}$ & \% \\
\hline $\begin{array}{l}\text { Primary Dryland Forest, } \\
\text { Mangrove Forest, Lake/Situ } \\
\begin{array}{l}\text { Water, Rivers, and Other } \\
\text { Bodies of Water }\end{array}\end{array}$ & 10 & 0,28 & 2,80 & Very Low & 61,93 & 3,20 \\
\hline $\begin{array}{l}\text { Burnt Rivers, Fish Ponds, Rice } \\
\text { Fields, And Tourism Areas }\end{array}$ & 20 & 0,28 & 5,60 & Low & 230,34 & 11,92 \\
\hline $\begin{array}{l}\text { Fields, Plantations, } \\
\text { Plantations/Gardens, and } \\
\text { Shrubs }\end{array}$ & 30 & 0,28 & 8,40 & Medium & 937,68 & 48,52 \\
\hline Open Field & 40 & 0,28 & 11,20 & High & 5,20 & 0,72 \\
\hline $\begin{array}{l}\text { Airstrip And Residential/Built- } \\
\text { Up Land }\end{array}$ & 50 & 0,28 & 14,00 & Very High & 697,38 & 36,09 \\
\hline
\end{tabular}

Table 3 shows that the land use with the widest emission potential is in the medium category with an area of $937.68 \mathrm{Ha}$ or about $48.52 \%$ of the city area. Next is land use with a very high 
emission potential category of $697.38 \mathrm{Ha}$ or around $36.09 \%$, followed by a low category road density with an emission potential of 230.34 Ha or around $11.92 \%$ of the Mamuju City area.

\section{Emission Potential based on Hazard}

Mamuju Regency area which has the highest level of flood vulnerability with an area of 279.84 km2 which includes Mamuju, Kalukku, Papalang, Sampaga and Tommo Districts (Risma, 2019). In the discussion of this variable the level of disaster susceptibility is examined in three types of disasters that often occur in Mamuju, namely floods, landslides, and earthquakes. The disaster-prone map in Mamuju City can be seen in the following figure

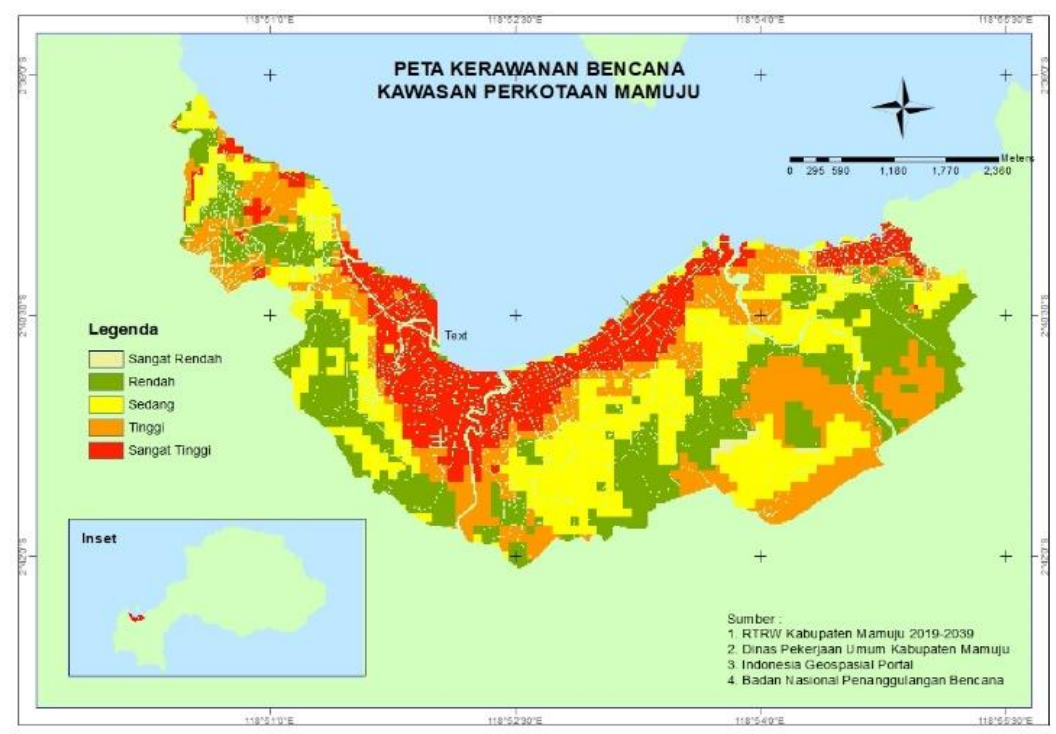

Figure 5. Map of Mamuju Urban Area Disaster Vulnerability Level

The potential emissions generated based on the thematic map of disaster vulnerability are shown in Table 4.

Table 4. Potential Emissions by Disaster Vulnerability Level

\begin{tabular}{|c|c|c|c|c|c|c|}
\hline Indicator & Score & Weight & $\begin{array}{c}\text { Score x } \\
\text { Weight }\end{array}$ & $\begin{array}{c}\text { Emission } \\
\text { Potential }\end{array}$ & $\begin{array}{c}\text { Surface } \\
(\text { Ha) }\end{array}$ & \% \\
\hline Very low & 10 & 0,20 & 2,00 & Very low & 8,21 & 0,42 \\
\hline Low & 20 & 0,20 & 4,00 & Low & 541,77 & 27,83 \\
\hline Medium & 30 & 0,20 & 6,00 & Medium & 555,52 & 28,54 \\
\hline High & 40 & 0,20 & 8,00 & High & 478,45 & 24,58 \\
\hline Very high & 50 & 0,20 & 10,00 & Very high & 562,82 & 18,64 \\
\hline
\end{tabular}

The emission potential with the largest area is the medium category emission potential with an area of $555.52 \mathrm{Ha}$ or $28.54 \%$ of the city area, then the disaster-prone area with a low category which has an area of $541.77 \mathrm{Ha}$ or about $27.83 \%$ difference $.71 \%$ with a medium area, then disaster-prone areas with high emission potential with an area of $478.45 \mathrm{Ha}$ or about $24.58 \%$, this area is only $77.07 \mathrm{Ha}$ apart from the medium category which has the highest area. The fourth largest emission potential is the very high category which has an area of $362.82 \mathrm{Ha}$ or 
$18.64 \%$ of the city area, and the last is the low emission potential category with an area of 8.21 Ha or about $0.42 \%$ of the city area.

\section{Potential Emissions by Population Density}

The population of Mamuju Regency is estimated to continue to grow based on population projections for 2010-2020 with an increase of around 70,000 thousand people from 232,490 thousand people in 2010 to 300,319 thousand people in 2020, the projection is estimated to be evenly distributed in all sub-districts in Mamuju Regency. (A \& Nuraini, 2015). The following is the population density per kelurahan in the Mamuju Urban Area

Table 5. Population Density in Mamuju Urban Area in 2020

\begin{tabular}{|c|c|c|c|c|c|}
\hline Districs & Village & $\begin{array}{c}\text { Total } \\
\text { Population } \\
\text { (Soul) }\end{array}$ & $\begin{array}{c}\text { Surface } \\
\text { Area }(\mathbf{k m 2})\end{array}$ & $\begin{array}{c}\text { Population } \\
\text { density } \\
\text { (Soul/ km2) }\end{array}$ & $\begin{array}{c}\text { Density } \\
\text { Level }\end{array}$ \\
\hline 1 & 2 & 3 & 4 & $3 / 4$ & 5 \\
\hline Mamuju & Binanga & 24.285 & 48,36 & 502 & Very low \\
\hline Mamuju & Mamunyu & 6.597 & 40,37 & 163 & Low \\
\hline Mamuju & Rimuku & 13.242 & 33,9 & 391 & Medium \\
\hline Mamuju & Karema & 12.587 & 41,2 & 306 & High \\
\hline Simboro & Simboro & 10.323 & 11,23 & 919 & Very high \\
\hline Simboro & Rangas & 3.719 & 33,6 & 140 & Very low \\
\hline \multicolumn{2}{|c|}{ Total } & $\mathbf{7 1 . 7 5 2}$ & $\mathbf{2 1 2 , 6 6}$ & $\mathbf{2 . 4 2 1}$ & \\
\hline
\end{tabular}

Source: BPS Mamuju Regency 2020

The population density map can be seen in Figure 6

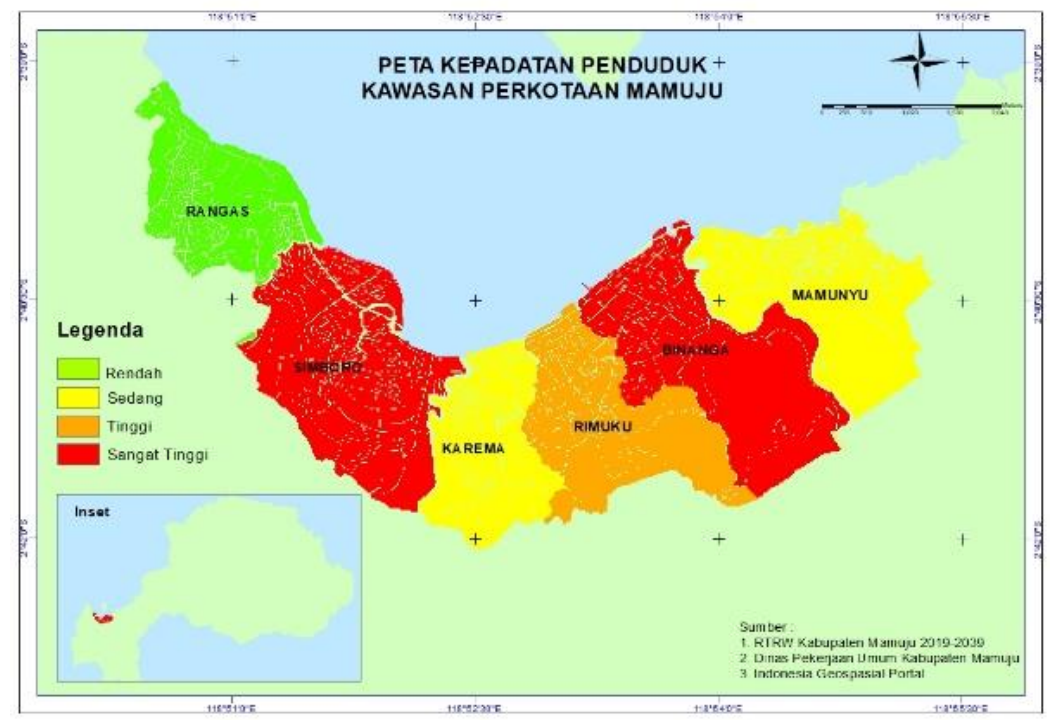

Figure 6. Map of Potential Emissions by Population Density

Population density is indicated to be directly proportional to its contribution to the potential for greenhouse gas emissions, meaning that the higher the population density, the higher the emissions produced in the area, the opposite applies. (P3E Sulawesi and Maluku, 2019). 
Estimates of potential emissions resulting from population density in the Mamuju city area can be seen in Table 6 .

Table 6. Potential Emissions by Population Density

\begin{tabular}{|c|c|c|c|c|c|c|}
\hline Indicator & Score & Weight & $\begin{array}{c}\text { Score x } \\
\text { Weight }\end{array}$ & $\begin{array}{c}\text { Emission } \\
\text { Potential }\end{array}$ & $\begin{array}{c}\text { Surface } \\
\text { (Ha) }\end{array}$ & $\%$ \\
\hline Very low & 10 & 0,20 & 2,2 & Very low & 0 & 0,00 \\
\hline Low & 20 & 0,20 & 4,4 & Low & 234,38 & 12,10 \\
\hline Medium & 30 & 0,20 & 6,6 & Medium & 555,77 & 28,69 \\
\hline High & 40 & 0,20 & 8,8 & High & 317,36 & 16,38 \\
\hline Very high & 50 & 0,20 & 11 & Very high & 829,72 & 42,83 \\
\hline
\end{tabular}

Based on the results of scoring and weighting, the population density level of the Mamuju urban area in 2020 consists of four categories, namely 2 villages in the very high category density level, namely Binanga Village and Simboro Village, 1 village in the high category namely Rimuku Village, 2 villages in the medium category, namely Mamunyu Village and Karema Village, and 1 sub-district in the low category, namely Rangas Village.

Population density in the Mamuju City area is classified in the low to very high range according to the data published by the Central Statistics Agency in 2019. Based on this data, the population density in the category of very high emission potential has the largest area of 829.72 $\mathrm{Ha}$ or $42.83 \%$ of the total area. the city, then the area with a population density of medium category with an area of $555.77 \mathrm{Ha}$ or $28.69 \%$ of the city area, then the area with a population density in the category of high emission potential with an area of $317.36 \mathrm{Ha}$ or $16.38 \%$, and finally the area with a population density in the category of low emission potential with an area of 234.38 ha or $12.10 \%$ of the Mamuju city area.

\section{Emission Potential Analysis of Mamuju Urban Area}

The emission potential analysis is the result of the spatial calculation of the emission potential of the variables, namely population density, road network, land use, and disaster-prone. The thematic maps of the four variable maps are then overlaid to produce the accumulation of potential emissions in the Mamuju urban area. The results of the overlay show areas with very high, high, medium, low, and very low emission levels and provide identification of areas whose emission levels need to be controlled by developing green open spaces. The map of the results of the overlay of four variables is shown in Figure 7.

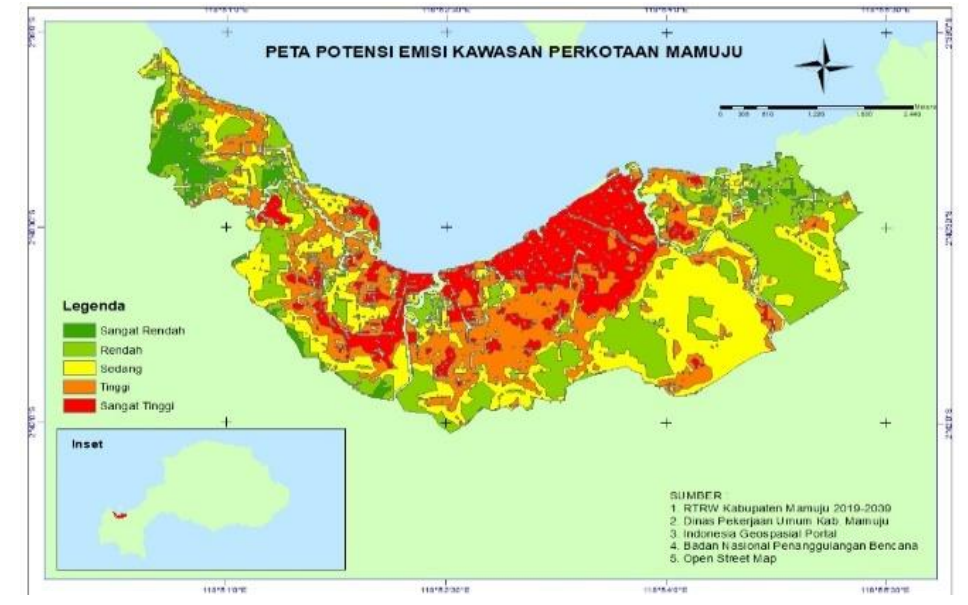

Figure 7. Map of Mamuju Urban Area Emission Potential 
At this stage, the results of the emission potential of the four variables are overlaid and attribute data is added in the form of the result of multiplying the score with the weight of each variable. From the overlay results, the emission potential values are very low to very high with the classification in Table 7.

Table 7. Distribution of Potential Emissions per Kelurahan

\begin{tabular}{|c|c|c|c|c|c|c|c|}
\hline Category & Binanga & Karema & Mamunyu & Rangas & Rimuku & Simboro & Total \\
\hline Very Low & 0,85 & 2,55 & 13,86 & 53,86 & 0,58 & 11,53 & 83,23 \\
\hline Low & 24,04 & 50,65 & 174,87 & 65,10 & 85,16 & 69,90 & 469,72 \\
\hline Medium & 180,10 & 50,86 & 79,28 & 56,54 & 65,35 & 131,22 & 563,34 \\
\hline High & 55,18 & 79,11 & 34,37 & 38,98 & 96,66 & 102,47 & 406,77 \\
\hline Very High & 139,90 & 32,90 & 7,52 & 0,03 & 60,93 & 74,14 & 315,41 \\
\hline Total & 400,07 & 216,07 & 309,88 & 214,51 & 308,67 & 389,27 & 1838,47 \\
\hline
\end{tabular}

The land use zones based on the results of overlaying indicator maps with the existing RTRW and Open Green Space can be seen in Table 8.

Table 8. Land Use Zones per Category of Potential Emissions

\begin{tabular}{|c|c|c|c|c|c|c|c|c|c|c|c|}
\hline $\begin{array}{c}\text { Catego } \\
\text { ry }\end{array}$ & $\begin{array}{l}\text { Industri } \\
\text { al Zone }\end{array}$ & $\begin{array}{c}\text { Trad } \\
\text { e and } \\
\text { servic } \\
\text { e } \\
\text { zone }\end{array}$ & $\begin{array}{c}\text { offic } \\
\text { e } \\
\text { zone }\end{array}$ & $\begin{array}{c}\text { Local } \\
\text { protecti } \\
\text { on zone }\end{array}$ & $\begin{array}{c}\text { Protection } \\
\text { Zone } \\
\text { Against } \\
\text { Subordina } \\
\text { te Areas }\end{array}$ & $\begin{array}{l}\text { Residenti } \\
\text { al Zone }\end{array}$ & $\begin{array}{c}\text { Mixed } \\
\text { Designat } \\
\text { ed Zone }\end{array}$ & $\begin{array}{c}\text { Other } \\
\text { Designat } \\
\text { ed Zones }\end{array}$ & $\begin{array}{l}\text { Gree } \\
\text { n } \\
\text { open } \\
\text { space } \\
\text { zone }\end{array}$ & $\begin{array}{c}\begin{array}{c}\text { Zone } \\
\text { of }\end{array} \\
\text { public } \\
\text { service } \\
\text { faciliti } \\
\text { es }\end{array}$ & $\begin{array}{c}\text { Gran } \\
\text { d } \\
\text { Total }\end{array}$ \\
\hline $\begin{array}{l}\text { Very } \\
\text { Low }\end{array}$ & & 1,90 & 0,56 & 4,16 & 0,54 & 40,36 & 5,33 & 7,18 & 18,56 & 4,55 & 83,23 \\
\hline Low & 0,70 & 1,71 & 7,11 & 7,79 & 7,44 & 128,68 & 18,94 & 117,76 & $\begin{array}{c}171,7 \\
6\end{array}$ & 7,72 & 469,72 \\
\hline $\begin{array}{c}\text { Mediu } \\
\text { m }\end{array}$ & 1,03 & 0,27 & $\begin{array}{c}22,7 \\
3\end{array}$ & 6,79 & 8,90 & 201,09 & 32,56 & 64,07 & $\begin{array}{c}214,0 \\
8\end{array}$ & 11,67 & 563,34 \\
\hline High & 0,32 & 1,95 & $\begin{array}{c}24,7 \\
5\end{array}$ & 3,55 & 0,44 & 232,83 & 83,67 & 9,04 & 26,98 & 23,23 & 406,77 \\
\hline $\begin{array}{l}\text { Very } \\
\text { High }\end{array}$ & & 5,89 & $\begin{array}{c}72,4 \\
7 \\
\end{array}$ & 1,93 & 0,00 & 121,31 & 136,56 & 1,35 & 3,56 & 27,50 & 315,41 \\
\hline $\begin{array}{c}\text { Grand } \\
\text { Total }\end{array}$ & 2,06 & 11,81 & $\begin{array}{c}72,4 \\
7\end{array}$ & 24,38 & 17,32 & 724,22 & 277,05 & 199,56 & $\begin{array}{c}434,9 \\
4\end{array}$ & 74,67 & $\begin{array}{c}1838,4 \\
7\end{array}$ \\
\hline
\end{tabular}

The category of very high emission potential land use is dominated by mixed designation zones of $136.56 \mathrm{Ha}$, housing zones $121.31 \mathrm{Ha}$, public service facilities zones $27.50 \mathrm{Ha}$, office zones 17.31 Ha, trade and service zones $5.89 \mathrm{Ha}$, space zones green open area $3.56 \mathrm{Ha}$, local protection zone $1.93 \mathrm{Ha}$, other designation zone $1.35 \mathrm{Ha}$, and there is no protection zone for subordinate areas and industrial zones. When viewed from the total land use zones of all categories, the residential zone is the highest percentage of the other zones.

\section{Directions for Open Green Space Planning in Mamuju Urban Area}

Of the 4 (four) variables determined in this study, the direction for the development of green open space in the Mamuju Urban Area by considering the results of the overlay of these variables is limited in the scope of the category of high and very high emission potential with an area of $722.18 \mathrm{Ha}$, the basis for giving directions can be seen in the following table:

Table 9. Green Open Space Planning Directions in Mamuju Urban Area.

\begin{tabular}{|l|l|l|l|}
\hline Emission potential & RT/RW & $\begin{array}{l}\text { RTH Existing } \\
\text { Map }\end{array}$ & $\begin{array}{l}\text { RTH Development } \\
\text { Direction }\end{array}$ \\
\hline Tall and "very high" & Industrial Zone & $\begin{array}{l}\text { Not green open } \\
\text { space ruang }\end{array}$ & $\begin{array}{l}\text { Improved vegetation with } \\
\text { high emission binding }\end{array}$ \\
\hline
\end{tabular}




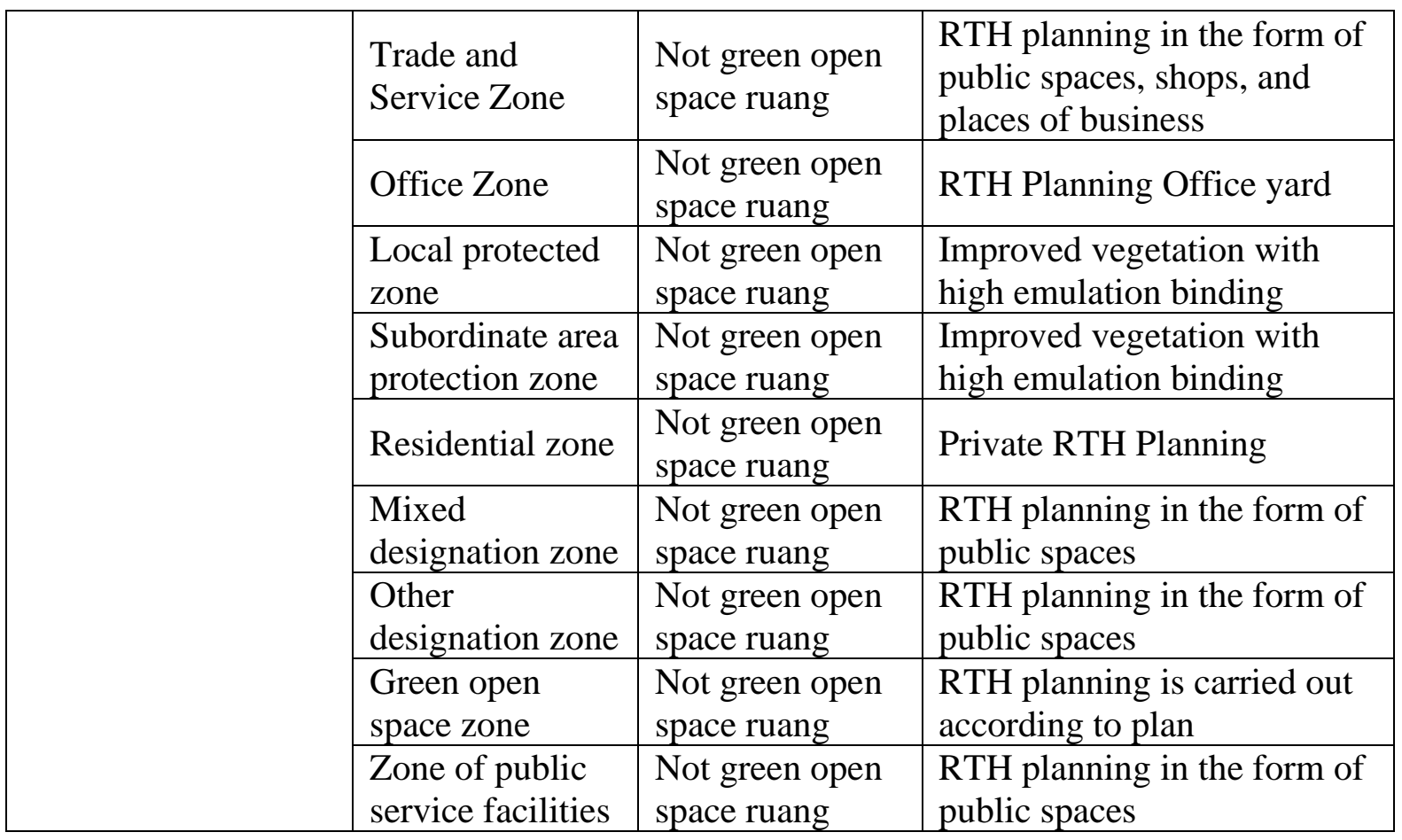

For the broad distribution of the direction for the development of RTH (Green Open Space) for the Mamuju Urban Area, it is shown in Table 10.

Table 10. Green Open Space Planning Directions in Mamuju Urban Area

\begin{tabular}{|l|c|c|}
\hline \multicolumn{1}{|c|}{ RTH Planning Direction } & Has & \% \\
\hline Increased vegetation with high emission binding power & 6,25 & 0,87 \\
\hline RTH Planning in the form of Public Space & 281,35 & 38,96 \\
\hline $\begin{array}{l}\text { RTH planning in the form of public spaces, shops and } \\
\text { businesses }\end{array}$ & 7,84 & 1,09 \\
\hline RTH planning is carried out as planned (RTRW) & 30,54 & 4,23 \\
\hline Planning RTH office yard & 42,06 & 5,82 \\
\hline Private RTH Planning & 354,14 & 49,04 \\
\hline Total Area & $\mathbf{7 2 2 , 1 8}$ & $\mathbf{1 0 0}$ \\
\hline
\end{tabular}

Table 10 shows that the largest green open space planning direction is on the development of "private green open space" with an area of $354.14 \mathrm{Ha}$ or $49.04 \%$ which focuses on planning for housing zones in the RTRW of Mamuju Regency and is located in an area with high and very high emission potential categories. Next is the planning of green open space in the form of public space with an area coverage of 289.19 Ha or about $40.04 \%$ of the area with high and very high emission potential, the area is a trade zone, mixed designation, other designations, and service facilities zone. general. The map for green open space planning for the Mamuju Urban Area can be seen in Figure 8 


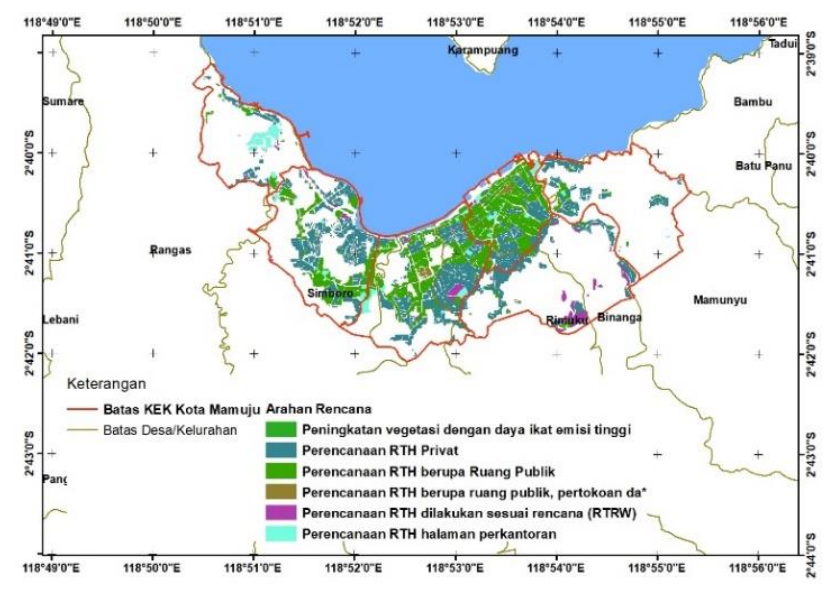

Figure 8. Map of Mamuju Urban Green Open Space Planning Directions

\section{Conclusion}

Green open space in the Mamuju Urban Area has decreased by 23 points from 2016 to 2020. Meanwhile, the direction of green open space planning in the Mamuju Urban Area is focused on the "high" and "very high" emission category areas which are priority areas for the development of green open space. . With the direction of RTH planning in the form of public spaces, shops, and places of business with an area of $289.19 \mathrm{Ha}$; planning of green space office yard with an area of $42.06 \mathrm{Ha}$; increased vegetation with high emission binding capacity with an area of $6.25 \mathrm{Ha}$; planning of private green open space with an area of 354.14 ha; and RTH planning is carried out according to the RTRW with an area of $30.54 \mathrm{Ha}$.

\section{References}

A, A. N. D., \& Nuraini. (2015). Proyeksi Penduduk Kabupaten/Kota Provinsi Sulawesi Barat 2010-2020. Badan Pusat Statistik.

Ahmad, F., Arifin, H. S., \& Dahlan, E. N. (2012). Analisis Hubungan Luas RTH dan Perubahan Suhu di Kota Palu. Jurnal Hutan Tropis, 13(2), 173-180.

Buhaug, H., \& Urdal, H. (2013). An urbanization bomb? Population growth and social disorder in cities. Global environmental change, 23(1), 1-10.

Dyson, T. (2011). The role of the demographic transition in the process of urbanization. Population and development review, 37, 34-54.

Farrell, K. (2017). The rapid urban growth Triad: A new conceptual framework for examining the urban transition in developing countries. Sustainability (Switzerland), 9(8), 1-19. https://doi.org/10.3390/su9081407

Fatimah, I. S., Munandar, A., Sinukaban, N., \& Kholil. (2011). Aplikasi Program Analisis Citygreen 5.4 Untuk Kajian Ruang Terbuka Hijau dan Manfaat Layanan Terukur Ekosistem Kota Bogor. Ekologia, 11(1), 1-11.

Mamuju, D. perumahan kawasan pemukiman dan pertanahan K. (2019). Laporan Akhir Rencana Pengembangan RTH Kab. Mamuju Tahun 2019.

Nastiti, F. N., \& Giyarsih, S. R. (2019). Green Open Space in Urban Areas: A Case in the Government Office of Boyolali, Indonesia. Regional Science Inquiry, 11(1), 19-28.

P3E Sulawesi dan Maluku. (2019). Arahan rencana pengelolaan sumber daya alam dan lingkungan hidup ekoregion pulau sulawesi. Pusat Pengendalian Pembangunan 
Ekoregion Sulawesi dan Maluku.

Risma. (2019). Prediksi dan Upaya Pengendalian Lokasi Rawan Banjir Kabupaten Mamuju. Universitas Hasanuddin.

Ruslan, M., \& Rahmad, B. (2012). Kajian Ruang Terbuka Hijau dalam rangka pembentukan Hutan Kota di Banjarbaru. 13(1).

Sesanti, N., Kurniawan, E. B., \& Anggraeni, M. (2011). Optimalisasi Hutan Sebagai Penghasil Oksigen Kota Malang. Jurnal Tata Kota Dan Daerah, 3(1), 65-74. 